\title{
Alelopatia de Ambrosia artemisiifolia na germinação e no crescimento de plântulas de milho e soja
}

\section{Allelopathy of Ambrosia artemisiifolia on germination and growth of maize and soybean seedlings}

\author{
Felix B. Formigheiri, Lisandro T. S. Bonome*, Henrique von H. Bittencourt, Keidima Leite, \\ Maicon Reginatto e Leonardo K. Giovanetti
}

Universidade Federal da Fronteira Sul, Campus Laranjeiras do Sul, Laranjeiras do Sul, Paraná, Brasil

( ${ }^{\star} E-m a i l:$ lisandrobonome@gmail.com)

http://dx.doi.org/10.19084/RCA18074

Recebido/received: 2018.03.16

Aceite/accepted: 2018.05 .15

\section{R E S U M O}

Neste trabalho foi avaliada a influência de exsudados radiculares e de extrato aquoso da parte aérea de Ambrosia artemisiifolia na germinação, no vigor de sementes e no crescimento inicial de milho e soja. Foram realizados dois ensaios, o primeiro em esquema fatorial (2x2), milho e soja com e sem exsudato radicular, e o segundo em esquema fatorial (2x4), milho e soja nas concentrações de $0,25,50$ e $75 \%$ de extrato aquoso de parte aérea de $A$. artemisiifolia. O exsudato radicular de $A$. artemisiifolia afetou negativamente o vigor de sementes de milho, mas não a germinação. O exsudato radicular de $A$. artemisiifolia não influenciou a germinação nem o vigor de sementes de soja. A cultura do milho apresentou maior sensibilidade que a soja ao exsudato radicular. $\mathrm{O}$ extrato aquoso da parte aérea de $A$. artemisiifolia afetou negativamente o vigor de sementes de milho e o vigor e a germinação de sementes de soja, sendo a soja mais sensível aos efeitos alelopáticos do extrato. O extrato aquoso da parte aérea de $A$. artemisiifolia apresentou teor de fenóis totais de 11,13 $\mathrm{mg} \mathrm{g}^{-1}$ de biomassa seca da parte aérea, o que pode ser considerado um valor alto quando comparado ao de outras infestantes.

Palavras-chave: invasora, losna-do-campo, Zea mays L., Glycine max L., compostos fenólicos

\begin{abstract}
A B S T R A C T
In this work, the influence of root exudates and aqueous extract from Ambrosia artemisiifolia shoots on germination, seed vigor and initial development of corn and soybean were evaluated. Two experiments were carried out in a factorial scheme $(2 \times 2)$, corn and soybean with and without root exudate, and the second in a factorial scheme $(2 \times 4)$, corn and soybean at concentrations of $0,25,50$ and $75 \%$ of aqueous extract of $A$. artemisiifolia shoots. The root exudate of $A$. artemisiifolia negatively affected the vigor of maize seeds, but not germination. The root exudate of $A$. artemisiifolia did not influence the germination and vigor of soybean seeds. The corn crop was more sensitive than soybean to root exudate. The aqueous extract from $A$. artemisiifolia shoots negatively affected the vigor of maize seeds and the vigor and germination of soybean seeds, being the soybean crop more sensitive to the allelopathic effects of the extract. The aqueous extract from A. artemisiifolia shoots presented total phenol content of $11.13 \mathrm{mg} \mathrm{g}^{-1}$ of the dry mass, which can be considered a high value when compared to other weeds.
\end{abstract}

Keywords: weed, common ragweed, Zea mays L., Glycine max L., phenolic compounds.

\section{INTRODUÇÃo}

O Brasil vem-se destacando no cenário mundial pelo potencial de produção agrícola, sendo o milho e a soja duas das principais culturas para a produção de grãos. De acordo com dados da
CONAB (2017), na safra 2016/2017 estimou-se uma produção de 88,969 e 107,614 milhões de toneladas, de milho e soja, respectivamente. Dessa forma, essas culturas representam grande parte dos rendimentos agrícolas brasileiro, estando ligadas a diversas cadeias produtivas. 
Muitos fatores limitam a produtividade das culturas agrícolas, dentre eles, merecem destaque, os prejuízos causados pela interferência de infestantes. Os problemas podem ser devidos à competição por água, radiação solar e nutrientes, por serem hospedeiras de pragas e doenças, por exercerem efeitos alelopáticos, dificultarem a colheita, além dos custos adicionais dos métodos de controle (Vasconcelos et al., 2012).

A losna-do-campo (Ambrosia artemisiifolia L.) é originária da Europa e pertencente à família Asteraceae, possui ciclo anual e desenvolve-se nas regiões Centro Oeste, Sudeste e Sul do Brasil, apresentando potencial crescente de infestação em diversas culturas anuais de grãos (Corrêa, 1984). Também ocorre com frequência em jardins, pastagens e bermas de estradas, apresentando boa capacidade reprodutiva através da propagação por meio de sementes (DiTommaso, 2004).

Além dos problemas resultantes da interferência com as plantas cultivadas, a espécie A. artemissifolia vem apresentando biótipos tolerantes aos herbicidas. Falhas no controle dessas populações permitem o rebentamento rápido da planta a partir da base do caule, tornando-se com isso, uma planta infestante de difícil controle (Bohren, 2007).

Além da competição por recursos, supõe-se que a alelopatia também possa explicar a interferência de $A$. artemissifolia com as culturas. A alelopatia é definida como qualquer efeito, direto ou indireto, benéfico ou prejudicial, de uma planta ou de microrganismos sobre outras plantas, mediante a produção de compostos químicos que são libertados no ambiente (Rice, 1984).

Depois de libertados no ambiente os compostos alelopáticos precisam de ser absorvidos pela planta alvo, podendo à partir daí, atuar na fisiologia das plantas, alterando os processos de divisão e alongamento celular e modificando a ultraestrutura celular. Além disso, podem influenciar os mecanismos hormonais de indução de crescimento, permeabilidade das membranas celulares, abertura estomática, fotossíntese, respiração, síntese proteica, metabolismo de lipídios e dos ácidos gordos (Politycka, 1999; Einhellig, 2004; Sampietro et al., 2006).
Segundo Almeida (1991), os efeitos alelopáticos podem ser avaliados através da extração de partes do vegetal com água, sendo o extrato aquoso utilizado como meio de embebição em bioensaios de germinação de sementes. Desta forma, é possível observar os efeitos dos compostos alelopáticos sobre as espécies cultivadas, os quais expressam-se por inibição ou estímulo da germinação e do crescimento de plântulas (Vyvyan, 2002).

Diante do exposto, este estudo teve como objetivo avaliar a influência de exsudatos radiculares e extrato aquoso da parte aérea de losna-do-campo (A. artemisiifolia) na germinação e no crescimento inicial de plântulas de milho e soja.

\section{MATERIAL E MÉTODOS}

Os ensaios foram conduzidos no Laboratório de Fisiologia Vegetal da Universidade Federal da Fronteira Sul (UFFS), Campus Laranjeiras do Sul - Paraná, Brasil. Nos bioensaios foram testadas sementes comerciais de milho (Zea mays) cultivar '22D11', da empresa Sempre sementes, e sementes de soja (Glycine max) cultivar '96Y90' da Pionner ${ }^{\circledR}$.

Para a obtenção de extrato vegetal de $A$. artemissifolia, foi colhida em março de 2016, no município de Laranjeiras do Sul - PR, a parte aérea de plantas adultas em estádio vegetativo. Estas foram secas em estufa com circulação de ar forçada a $40{ }^{\circ} \mathrm{C}$ até atingir peso constante. Após a secagem, o material vegetal foi moído em moinho de facas do tipo Willey com tela malha $1 \mathrm{~mm}$, e imediatamente acondicionado em frascos de vidro vedados com Parafilm $M{ }^{\circledR}$.

Para a obtenção de sementes de $A$. artemisiifolia, aguardou-se a finalização do ciclo reprodutivo das plantas, sendo colhidas as sementes dos ramos terminais. Nolaboratório, foi realizada limpeza com soprador de sementes, para remoção de impurezas e sementes danificadas. As sementes foram acondicionadas em recipientes de vidro âmbar a temperatura de $5{ }^{\circ} \mathrm{C}$ até o momento da montagem dos testes.

O extrato aquoso da parte aérea foi obtido a partir da diluição de 25 gramas de biomassa seca do material vegetal em $225 \mathrm{~mL}$ de água destilada, homogeneizada em agitador orbital incubadora 
tipo shaker por 120 minutos a $230 \mathrm{rpm}$, a temperatura de $40{ }^{\circ} \mathrm{C}$. Após a homogeneização a mistura foi filtrada em gaze e centrifugada a $4000 \mathrm{rpm}$ por 10 minutos. O sobrenadante foi filtrado em filtro de papel com poros de $28 \mu \mathrm{m}$ para obtenção do extrato aquoso, que foi armazenado a $-4{ }^{\circ} \mathrm{C}$ até o momento de utilização.

\section{Bioensaio com exsudatos radiculares}

Para obtenção dos exsudatos radiculares, as sementes de $A$. artemisiifolia foram retiradas do armazenamento a frio $\left(5{ }^{\circ} \mathrm{C}\right)$ com antecedência de 24 horas para o equilíbrio com a temperatura ambiente e de seguida imersas em solução de giberelina a 500 ppm durante 12 horas para quebra de dormência. Após esse procedimento as sementes foram lavadas em água corrente e dispostas entre papel germitest umedecidos com água destilada em volume equivalente a 2,5 vezes a sua massa e levados para câmara de germinação onde permaneceram a temperatura de $25{ }^{\circ} \mathrm{C}$ até início da protrusão radicular.

Quatro repetições de duzentas e quarenta plântulas com aproximadamente $1 \mathrm{~mm}$ de raiz, foram transferidas para outro papel germitest, onde permaneceram por sete dias em câmara de germinação a $25^{\circ} \mathrm{C}$ para a formação de plântulas normais. Concluído este período as plântulas foram descartadas e o papel reutilizado contendo os exsudatos libertados pelas raízes das plântulas, para a realização dos testes alelopáticos.

\section{Bioensaio com extrato aquoso de parte área}

Neste bioensaio utilizou-se extrato aquoso da parte aérea de $A$. artemisiifolia como umidificante do papel germitest, sendo o papel umedecido 2,5 vezes a sua massa, sendo usadas concentrações de 25,50 e $75 \%$ (v/v) diluídas em água e como grupo controle utilizou-se papel germitest embebido em água destilada.

\section{Testes alelopáticos}

Os seguintes testes conducentes à avaliação dos efeitos alelopáticos com exsudados radiculares e extrato aquoso da parte aérea da infestante foram realizados: germinação, primeira contagem de germinação (quatro e cinco dias após a semeadura para milho e soja, respectivamente), índice de velocidade de germinação (IVG), crescimento de plântulas e biomassa seca de parte aérea e sistema radicular de milho e soja.

Os testes de germinação foram realizados com 4 repetições de 50 sementes de cada cultura. Cada espécie permaneceu no germinador pelo tempo recomendado pelas Regras para Análise de sementes (Brasil, 2009) e no final do teste foram contadas o número de plântulas normais e anormais e as sementes mortas e dormentes.

O índice de velocidade de germinação foi realizado conjuntamente com o teste de germinação. Para a avaliação do IVG, foram contabilizadas diariamente as plântulas normais a partir do surgimento da primeira plântula normal até que o número de plântulas se tornasse constante, sendo o IVG calculado pelo somatório do número de plântulas normais a cada dia, dividido pelo número de dias decorridos até à formação da plântula, utilizando como referência a fórmula proposta por Maguire (1962):

$\mathrm{IVG}=(\mathrm{G} 1 / \mathrm{N} 1)+(\mathrm{G} 2 / \mathrm{N} 2)+(\mathrm{G} 3 / \mathrm{N} 3)+\ldots+(\mathrm{Gn} / \mathrm{Nn})$.

O ensaio de crescimento de plântulas, tanto no exsudato radicular quanto no extrato aquoso de parte área de $A$. artemisiifolia, foi realizado com 5 repetições de 20 sementes para cada espécie, as quais permaneceram em germinador pelo período de tempo recomendado pelas Regras para Análise de Sementes (Brasil, 2009). No final do período, para ambas as culturas, realizou-se a aferição do comprimento da parte aérea e do sistema radicular com paquímetro digital.

Para biomassa seca de plântulas separou-se parte aérea e raízes as quais foram secas em estufa de circulação forçada de ar a $60{ }^{\circ} \mathrm{C}$ por 48 horas, antes de serem pesadas para aferição da biomassa seca.

\section{Quantificação de fenóis totais}

Para a determinação dos fenóis totais, $50 \mathrm{~mL}$ do extrato foi misturado a $150 \mathrm{~mL}$ de acetona PA. A solução foi submetida à agitação em agitador 
magnético em baixa velocidade a temperatura ambiente $\left(20^{\circ} \mathrm{C}\right)$ por período de 12 horas. A mistura foi filtrada sob vácuo em duas camadas de papel filtro com porosidade de $25 \mu \mathrm{m}$. O material retido no filtro foi descartado. A acetona da mistura foi removida com uso de evaporador rotativo a $40{ }^{\circ} \mathrm{C}$. O líquido resultante foi lavado com 3 porções de $150 \mathrm{~mL}$ de hexano e em seguida 3 vezes com $150 \mathrm{~mL}$ de éter. A fração contendo hexano foi descartada. A fração etérea foi levada a evaporador rotativo a $40{ }^{\circ} \mathrm{C}$ para remoção do éter obtendo-se após este processo o extrato bruto.

Para leitura no espectrofotómetro foram preparadas soluções com $50 \mu \mathrm{L}$ do extrato, $600 \mu \mathrm{L}$ de $\mathrm{NaCO} 3(7,5 \% \mathrm{~m} / \mathrm{v}), 750 \mu \mathrm{L}$ de água destilada e $200 \mu \mathrm{L}$ de reagente Folin-Ciocalteau. A mistura foi encubada por 10 minutos em banho maria a $50{ }^{\circ} \mathrm{C}$ e diluída com $1,0 \mathrm{~mL}$ de água destilada e de seguida acondicionada em cubetas em triplicata para leitura a $760 \mathrm{~nm}$. A curva analítica foi construída em função de concentrações $0,10,20,30$ e $40 \mu \mathrm{g} / \mathrm{mL}$ para o ácido gálico em $760 \mathrm{~nm}$.

\section{Delineamento experimental}

O delineamento experimental utilizado foi o inteiramente casualizado, em esquema fatorial $(2 \times 2)$ com 2 culturas (milho e soja) e 2 tratamentos (testemunha e exsudato radicular) para o bioensaio de exsudato radicular, e esquema fatorial $(2 \times 4)$ sendo 2 culturas (milho e soja) com 4 concentrações ( 0 , 25,50 e $75 \%$ v/v) de extrato aquoso de parte aérea de $A$. artemisiifolia. Os dados foram submetidos ao teste $\mathrm{F}(p<0,05)$, utilizando o programa estatístico Sisvar 5.6. Para os resultados do bioensaio de extrato aquoso foi realizada análise de regressão utilizando o programa estatístico Genes.

\section{RESULTADOS E DISCUSSÃO}

\section{Bioensaio com exsudato radicular}

Considerando os resultados apresentados no Quadro 1, o exsudato radicular de A. artemisiifolia apresentou influência negativa para os testes de vigor de primeira contagem de germinação e índice de velocidade de germinação na cultura do milho, porém não influenciou a porcentagem final de germinação. No entanto, o exsudato radicular não influenciou nenhum dos parâmetros avaliados da soja (Quadro 1).

O efeito prejudicial dos exsudatos no vigor do milho, mas não evidenciado na porcentagem de germinação pode ser explicado pelo fato da queda do vigor das sementes preceder a da germinação (Marcos-Filho, 2015). Assim, os testes de vigor fornecem índices mais sensíveis da qualidade fisiológica das sementes que o teste de germinação, sendo mais indicados para expressar interferências sobre o processo germinativo de sementes.

Os resultados deste trabalho estão de acordo com os obtidos por Pinto et al. (2011) com exsudato radicular de Amaranthus cruentus L. também com a soja. Esta observação sugere que esta cultura apresenta baixa sensibilidade no processo germinativo aos exsudatos radiculares de algumas espécies infestantes.

\section{Crescimento e biomassa seca de plântulas}

Os resultados de crescimento e biomassa seca de parte aérea e raízes (Quadro 2), mostram efeito negativo dos exsudatos radiculares de $A$. artemisiifolia na acumulação de biomassa seca de raiz em plântulas de milho. Houve redução da alocação

Quadro 1 - Germinação de sementes de milho e soja em exsudato radicular de losna-do-campo (Ambrosia artemisiifolia L.)

\begin{tabular}{|c|c|c|c|c|c|c|}
\hline \multirow[b]{2}{*}{ Tratamento } & \multicolumn{2}{|c|}{$1^{\text {a }}$ Contagem $(\%)$} & \multicolumn{2}{|c|}{ Germinação (\%) } & \multicolumn{2}{|c|}{ IVG } \\
\hline & Sem exsudato & Com exsudato & Sem exsudato & Com exsudato & Sem exsudato & Com exsudato \\
\hline Milho & $81 \mathrm{Aa}$ & $55 \mathrm{Bb}$ & $94 \mathrm{Aa}$ & $91 \mathrm{Aa}$ & $11,35 \mathrm{Aa}$ & $10,40 \mathrm{Ba}$ \\
\hline Soja & 81Aa & $74 \mathrm{Aa}$ & 98Aa & 93Aa & $10,78 \mathrm{Aa}$ & $10,03 \mathrm{Aa}$ \\
\hline $\mathrm{CV} \%$ & \multicolumn{2}{|c|}{11,42} & \multicolumn{2}{|c|}{4,06} & \multicolumn{2}{|c|}{4,66} \\
\hline
\end{tabular}

Médias seguidas de mesma letra maiúscula na linha (dentro da mesma cultura e para a mesma variável), e minúscula na coluna (dentro dos tratamentos) não diferem entre si pelo teste $\mathrm{F}$ a $5 \%$ de probabilidade. 
Quadro 2 - Comprimento e massa seca da parte aérea e raiz de plântulas de milho e soja em exsudato radicular de losna-docampo (Ambrosia artemisiifolia L.)

\begin{tabular}{|c|c|c|c|c|c|c|c|c|}
\hline & \multicolumn{2}{|c|}{$\begin{array}{l}\text { Comprimento Parte Aérea } \\
(\mathrm{mm})\end{array}$} & \multicolumn{2}{|c|}{$\begin{array}{l}\text { Comprimento } \\
\text { Raiz (mm) }\end{array}$} & \multicolumn{2}{|c|}{$\begin{array}{c}\text { Massa Seca Parte } \\
\text { Aérea (g) }\end{array}$} & \multicolumn{2}{|c|}{$\begin{array}{c}\text { Massa seca } \\
\text { Raiz (g) }\end{array}$} \\
\hline & $\begin{array}{c}\text { Sem } \\
\text { exsudato }\end{array}$ & $\begin{array}{l}\text { Com } \\
\text { exsudato }\end{array}$ & $\begin{array}{c}\text { Sem } \\
\text { exsudato }\end{array}$ & $\begin{array}{l}\text { Com } \\
\text { exsudato }\end{array}$ & $\begin{array}{c}\text { Sem } \\
\text { exsudato }\end{array}$ & $\begin{array}{c}\text { Com } \\
\text { exsudato }\end{array}$ & $\begin{array}{c}\text { Sem } \\
\text { exsudato }\end{array}$ & $\begin{array}{c}\text { Com } \\
\text { exsudato }\end{array}$ \\
\hline Milho & $123,23 \mathrm{Aa}$ & $137,63 \mathrm{Aa}$ & $201,45 \mathrm{Aa}$ & $194,78 \mathrm{Aa}$ & 0,807Aa & 0,849Aa & $0,682 \mathrm{Aa}$ & $0,420 \mathrm{Ba}$ \\
\hline Soja & $120,04 \mathrm{Ba}$ & $151,17 \mathrm{Aa}$ & $164,40 \mathrm{Ab}$ & $144,49 \mathrm{Ab}$ & $0,581 \mathrm{Ab}$ & $0,597 \mathrm{Ab}$ & $0,149 \mathrm{Ab}$ & $0,139 \mathrm{Ab}$ \\
\hline CV\% & \multicolumn{2}{|c|}{14,96} & \multicolumn{2}{|c|}{11,88} & \multicolumn{2}{|c|}{6,41} & \multicolumn{2}{|c|}{15,23} \\
\hline
\end{tabular}

Médias seguidas de mesma letra maiúscula na linha (dentro da mesma cultura e para a mesma variável), e minúscula na coluna (dentro dos tratamentos) não diferem entre si pelo teste $\mathrm{F}$ a $5 \%$ de probabilidade.

de biomassa seca para as raízes de aproximadamente $38 \%$ em relação à testemunha. De acordo com Marcos-Filho et al. (1999) a determinação da biomassa seca é um dos principais indicadores de avaliação do vigor de sementes, pois representa a capacidade de transferência de biomassa seca dos tecidos de reserva para o eixo embrionário, podendo expressar a qualidade de plântulas.

Diversos trabalhos têm mostrado que compostos fenólicos como o ácido cumárico, ácido ferúlico, ácido caféico, catequina, epicatequina, entre outros, podem alterar a fisiologia da planta por diferentes mecanismos (Patterson, 1981; Yu et al., 2003; Fujji \& Hiradate, 2007). Entre os efeitos estão a lignificação precoce das paredes celulares de células radiculares (Politycka, 1999), a redução da divisão celular e alteração da morfologia das raízes (Sampietro et al., 2006). Estes efeitos podem assim ter influenciado a acumulação de biomassa seca do sistema radicular de plântulas de milho.

Na cultura da soja foi observado efeito positivo do exsudato radicular de $A$. artemisiifolia no crescimento de parte aérea das plântulas, com incremento de aproximadamente $25 \%$ no comprimento em relação à testemunha (Quadro 2).

\section{Bioensaio com extrato aquoso de parte aérea}

$\mathrm{O}$ extrato aquoso de $A$. artemisiifolia afetou negativamente o vigor de milho e soja, sendo este efeito diretamente proporcional à concentração do extrato (Figura 1).

De acordo com Nakagawa (1999) a primeira contagem da germinação avalia a porcentagem de plântulas normais que são obtidas por ocasião da primeira contagem do teste de germinação na amostra em análise, sendo eficiente para determinar o vigor das sementes. Assim, este é um importante parâmetro para expressar efeitos negativos ou positivos por interferência de compostos alelopáticos no processo germinativo de sementes.

As duas culturas apresentaram comportamento semelhante, linear decrescente, em resposta ao aumento da concentração do extrato da parte aérea de $A$. artemisiifolia (Figura 1).

Corroborando com o observado no teste de primeira contagem de germinação o extrato aquoso de $A$. artemisiifolia prejudicou significativamente o índice

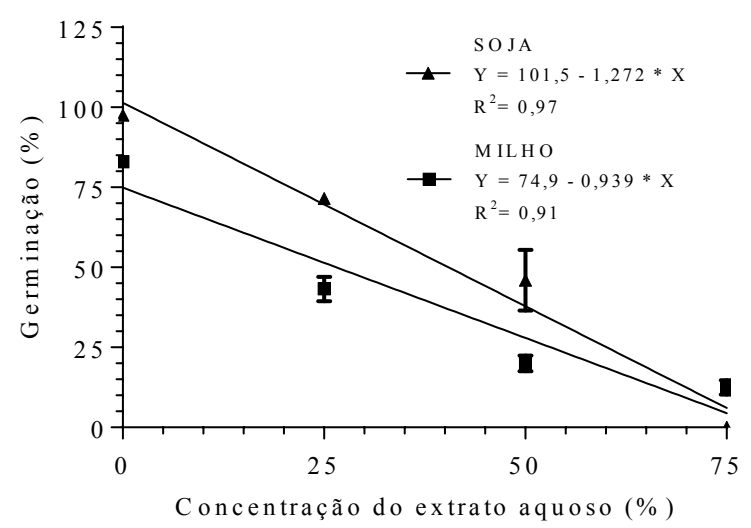

Figura 1 - Germinação (\%) de sementes de milho e soja, primeira contagem (efetuada quatro e cinco dias após a semeadura para milho e soja, respectivamente), em função de diferentes concentrações de extrato aquoso da parte aérea de Ambrosia artemisiifolia L. 
de velocidade de germinação (IVG), causando redução linear deste parâmetro com o aumento da concentração de extrato aplicado em ambas as espécies avaliadas (Figura 2).

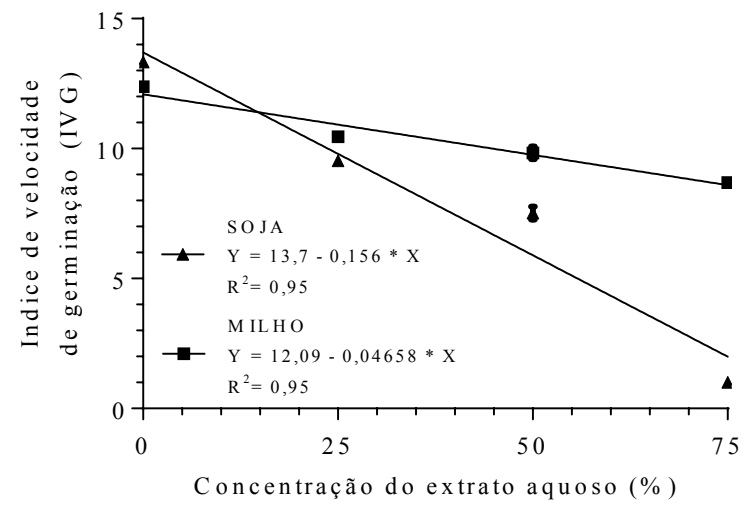

Figura 2 - Índice de velocidade de germinação de plântulas de milho e soja em função de diferentes concentrações de extrato aquoso da parte aérea de $\mathrm{Am}$ brosia artemisiifolia.

De acordo com Ferreira e Áquila (2000), comumente o efeito alelopático não se manifesta diretamente sobre a porcentagem de germinação total, mas pode influenciar a velocidade de germinação ou outra característica do processo germinativo. O tempo de germinação é um fator crucial para a sobrevivência das plântulas, refletindo sobre o crescimento e desempenho nos estágios subsequentes do desenvolvimento (Fenner, 2000). Sementes que germinam mais lentamente podem dar origem a plântulas com tamanho reduzido e, como consequência, podem ser mais suscetíveis a estresses e predação, tendo então menor chance na competição por recursos (Jefferson e Pennachio, 2003). Por ser o índice de velocidade de germinação um teste mais sensível do que o de germinação, tem sido frequentemente utilizado para avaliar a influência de extratos vegetais no vigor de sementes. Scheren et al. (2014) relataram redução na velocidade de germinação de milho em extratos aquosos de diferentes concentrações de tubérculos/ rizoma e de parte aérea de Cyperus rotundus. Já em estudo com cultivares de soja, Corsato et al. (2010) verificaram diminuição no tempo médio e velocidade média de germinação quando as sementes foram mantidas na presença de extratos aquosos de folhas de girassol nas concentrações de 20, 40 e $60 \%$.

O crescimento da parte aérea de ambas as culturas avaliadas (milho e soja) foi afetado pelo extrato aquoso de $A$. artemisiifolia, mesmo na menor concentração aplicada, 25\% (Figura 3 A). Todavia esse decréscimo no comprimento das plântulas de milho e soja foi intensificado com o aumento da concentração do extrato.

As sementes de soja apresentaram maior sensibilidade ao extrato aquoso de $A$. artemisiifolia do que as de milho em todas as concentrações utilizadas, mas essa diferença foi mais pronunciada no extrato com concentração de 75\% (Figura 3 A e B).

Iganci et al. (2006) destacam que o efeito de compostos alelopáticos geralmente é mais drástico sobre o crescimento do que na germinação, tendo o desenvolvimento de plântulas uma maior
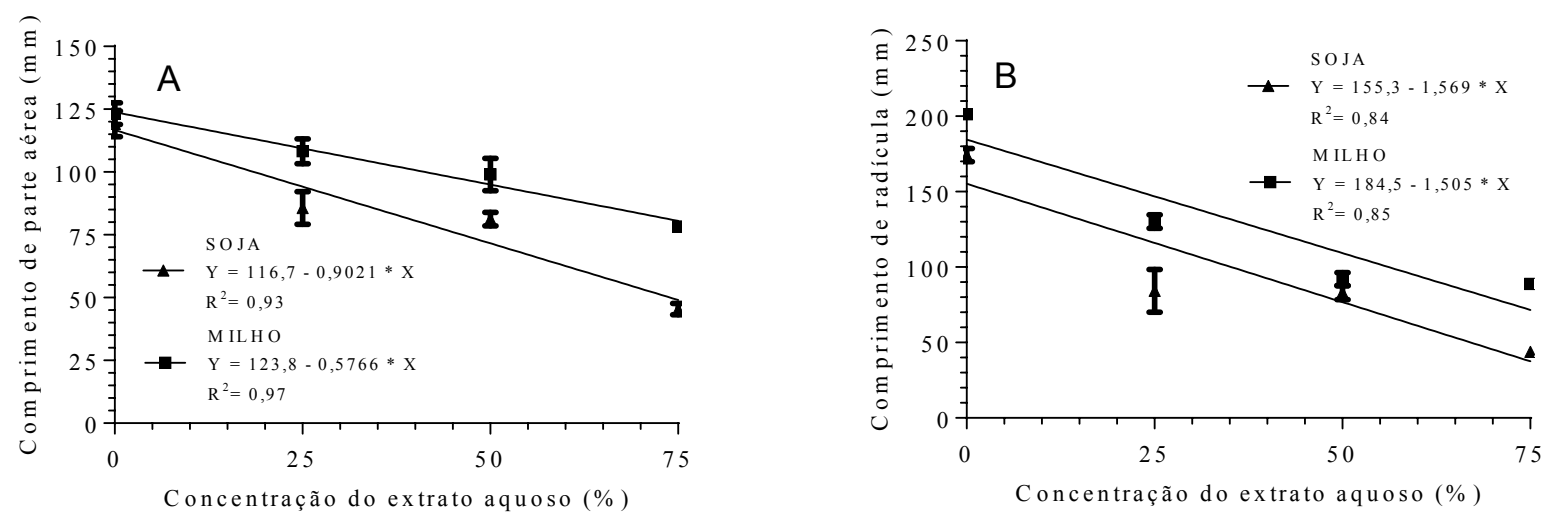

Figura 3 - Comprimento da parte aérea (A) e da radícula (B) de plântulas de milho e soja em função de diferentes concentrações de extrato aquoso da parte aérea de Ambrosia artemisiifolia $\mathrm{L}$. 
sensibilidade e, consequentemente, respostas mais visíveis à influência alelopática. As alterações induzidas por substâncias alelopáticas no desenvolvimento inicial de plântulas podem resultar de diversos efeitos causados no metabolismo primário. Dentre as quais podem-se destacar alterações na permeabilidade de membranas, na transcrição e tradução do DNA, no funcionamento de mensageiros secundários, na respiração, na conformação de enzimas e receptores, ou ainda, pela combinação destes fatores (Ferreira, 2004).

Semelhante ao observado na primeira contagem de germinação, índice de velocidade de germinação e crescimento da parte aérea de plântulas, o extrato aquoso de $A$. artemisiifolia contribuiu para a redução do comprimento radicular das espécies avaliadas (Figura 3B).

As plântulas das duas espécies apresentaram redução no comprimento do sistema radicular a partir da concentração de $25 \%$ do extrato aquoso, sendo essa redução proporcional ao aumento da concentração de extrato. $\mathrm{Na}$ concentração de $75 \%$, as espécies de milho e soja apresentaram comprimento médio do sistema radicular aproximadamente $50 \%$ menor quando comparado com plântulas testemunha. Contudo a soja apresentou maior sensibilidade aos efeitos do extrato aquoso de $A$. artemisiifolia do que o milho. Em ambas as espécies foram registradas anormalidades, principalmente no sistema radicular, a partir da concentração de $50 \%$ do extrato. Os sintomas mais comuns foram: raízes atrofiadas, curtas e defeituosas, com medidas desproporcionais em relação às outras estruturas da planta. Na concentração de $75 \%$ do extrato observou-se oxidação e necrose das raízes de plântulas de soja. A anormalidade de plântulas é um instrumento valioso em ensaios com alelopatia, sendo a necrose da raiz o sintoma mais comum da anormalidade (Ferreira e Áquila, 2000).

De acordo com Chon et al. (2000) as raízes são mais sensíveis às substâncias que estão presentes nos extratos, em comparação com as demais estruturas das plântulas. A maior sensibilidade é explicada pelo fato das raízes permanecerem em contato direto e prolongado com o extrato (aleloquímicos) em relação às outras estruturas das plântulas e/ou a um reflexo da fisiologia distinta entre as estruturas (Áquila, 2000).

Carvalho et al. (2014) apontam que o sistema radicular das plantas é mais sensível à ação de aleloquímicos, porque o seu alongamento depende de divisões celulares, que, se inibidas, comprometem o seu desenvolvimento normal. Os ácidos fenólicos são potentes aleloquímicos que induzem o aumento da atividade de enzimas oxidativas, tendo como consequência final a modificação da permeabilidade das membranas e a formação de lenhina, que contribuem para a redução do alongamento radicular (Ferrarese et al., 2000).

As duas espécies cultivadas tiveram menor acumulação de biomassa seca de raiz e parte aérea quando germinadas em extrato aquoso de $A$. artemisiifolia, sendo essa redução diretamente proporcional ao aumento da concentração do extrato aquoso (Figura 4A e 4B).
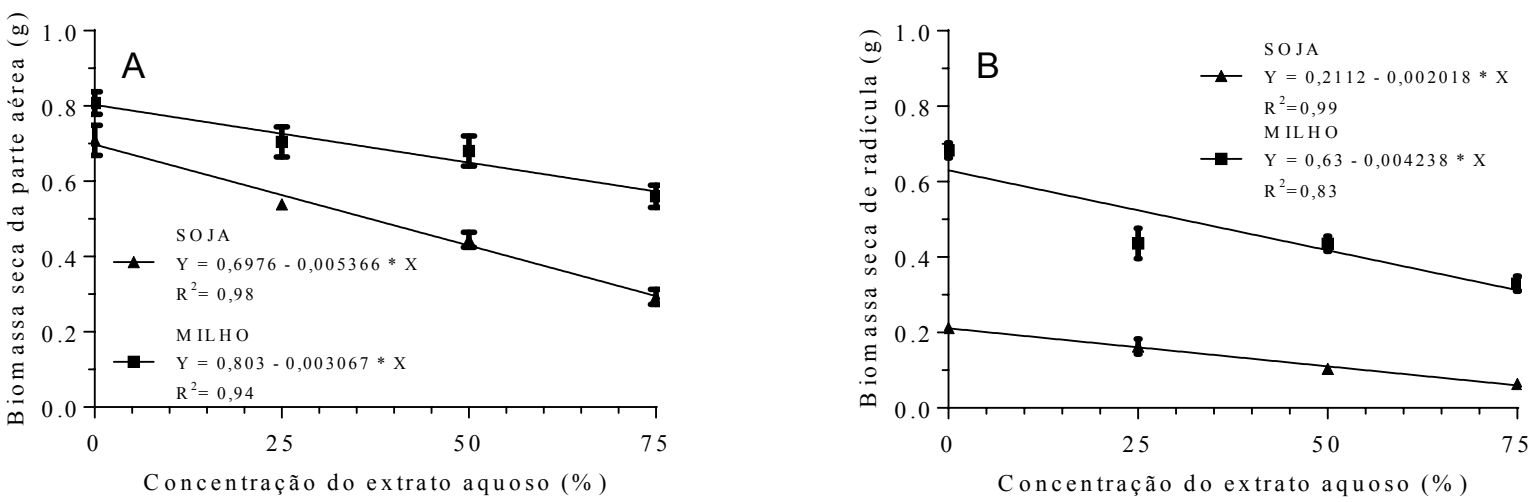

Figura 4 - Biomassa seca da parte aérea (A) e de radícula (B) de plântulas de milho e soja em função de diferentes concentrações de extrato aquoso da parte aérea de Ambrosia artemisiifolia $\mathrm{L}$. 
Os resultados indicam maior sensibilidade da cultura da soja ao extrato aquoso de $A$. artemisiifolia em relação ao milho, cuja concentração de $75 \%$ promoveu redução de aproximadamente 50\% da biomassa seca de parte aérea e raiz quando em comparação com a testemunha.

Destaca-se que o extrato aquoso de $A$. artemisiifolia afetou negativamente todos os parâmetros de vigor analisados nas duas espécies de plantas cultivadas. Os resultados observados indicam a possível ocorrência de efeito alelopático da cobertura morta da infestante sobre milho e soja no campo, mas que precisam de ser confirmados.

De acordo com Hong et al. (2004) a redução da biomassa seca está relacionada com a inibição de mecanismos de hidrólise dos materiais de reserva ou com danos da estrutura celular, afetando assim a transferência de reservas do endosperma ou dos cotilédones para o eixo embrionário da semente, resultando em menor acumulação de biomassa seca em plântulas.

Neste estudo também foi observada influência do extrato aquoso de $A$. artemisiifolia na porcentagem de germinação da cultura da soja, cuja concentração de $75 \%$ do extrato reduziu de maneira significativa o número de plântulas normais (Figura 5), observando-se atrofia da parte aérea e atraso no crescimento das plântulas. Nesse caso, as plântulas de soja permaneceram com o tegumento da semente aderido aos cotilédones impedindo a

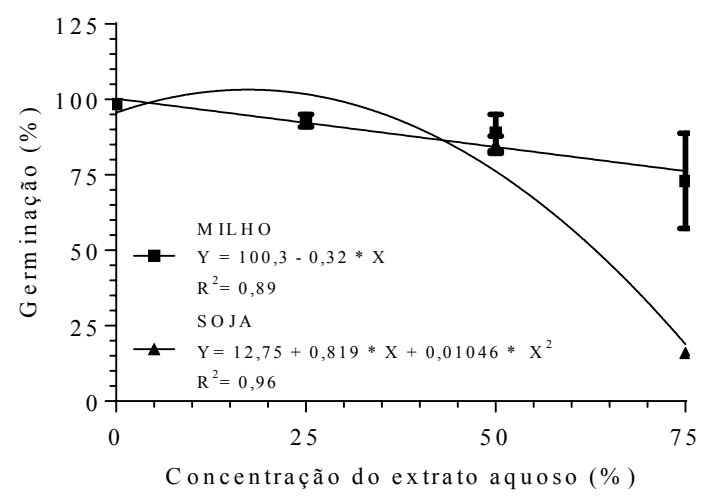

Figura 5 - Germinação (\%) de sementes de milho e soja em função de diferentes concentrações de extrato aquoso da parte aérea de Ambrosia artemisiifolia L. libertação dos folíolos, o que não foi observado no milho.

Gonzalez et al. (2002) relatam que no processo germinativo, juntamente com a água, podem penetrar algumas substâncias alelopáticas capazes de inibir ou retardar a multiplicação ou crescimento das células, podendo também retardar a germinação. Esta ação pode ser potencializada por altas concentrações de extrato devido a maior presença de substâncias tóxicas. Para Muniz et al. (2007) a diminuição do número de sementes germinadas está relacionada com a interferência causada pelos compostos fenólicos sobre as vias de hidrólise de reserva. Isto pode ter sido a causa do aumento de plântulas anormais na concentração de $75 \%$ de extrato na cultura da soja.

Na cultura do milho, o extrato aquoso de A. artemisiifolia não influenciou na germinação das sementes independentemente da concentração utilizada. Todavia, o vigor das sementes - medido pelos testes de primeira contagem da germinação e índice de velocidade de germinação, crescimento e biomassa seca da parte aérea e raiz - , foi severamente prejudicado com o incremento da concentração do extrato aquoso de $A$. artemisiifolia, atrasando o crescimento das plântulas, o que pode torná-las mais vulneráveis às variações edafoclimáticas.

\section{Quantificação de fenóis totais}

$\mathrm{O}$ extrato aquoso da parte aérea de $A$. artemisiifolia apresentou teor de fenóis totais de $11,13 \mathrm{mg} \mathrm{g}^{-1}$ de biomassa seca da planta. An et al. (2001) associam elevados teores de fenóis totais em extrato aquoso a altos níveis de inibição no crescimento de plantas, sendo a quantidade de fenóis totais em solução um parâmetro indicativo para potencial fitotóxico. O resultado obtido foi semelhante ao registrado por Weiler et al. (2010) para o extrato de acetato de metilo das folhas secas de Ipomoea cairica (L.) Sweet. (Convolvulaceae) e aproximadamente 5 vezes menor que o valor registrado para o extrato de acetato de etilo para folhas secas da Bignoniaceae Pyrostegia venusta (Ker Gawl.) Miers (Silva et al., 2011).

Baseado nos resultados obtidos no presente trabalho, pode-se inferir que a $A$. artemisiifolia pode 
prejudicar a produtividade de milho e soja pela libertação de compostos químicos no ambiente que podem ocorrer tanto pela exsudação radicular quanto pela decomposição da biomassa da parte radicular e aérea e não apenas devido à competição por recursos como a água, luz e nutrientes minerais. Os metabolitos libertados pela infestante afetam o vigor das sementes e o crescimento de plântulas de milho e soja e seus efeitos são diretamente proporcionais ao volume de biomassa em decomposição. Neste contexto, no programa de gestão deve constar o controle precoce de populações de A. artemisiifolia em áreas de lavoura de milho e soja, evitando o seu estabelecimento e crescimento e reduzindo com isso, a libertação de compostos alelopáticos no solo. Por fim, a constatação de efeitos fitotóxicos da $A$. artemisiifolia sobre as culturas de interesse económico sugere a necessidade de isolar, identificar e avaliar a fitotoxidade isolada dos aleloquímicos presentes na losna-do-campo (A. artemisiifolia) a fim de verificar a sua potencialidade como bioherbicida.

\section{CONCLUSÕES}

$\mathrm{O}$ exsudato radicular de $A$. artemisiifolia afetou negativamente o vigor de sementes de milho, mas não a germinação.

O exsudato radicular de $A$. artemisiifolia não influênciou a germinação nem o vigor de sementes de soja.

A cultura do milho apresentou maior sensibilidade a efeitos alelopáticos de exsudato radicular de $A$. artemisiifolia em comparação a cultura da soja.

O extrato aquoso da parte aérea de $A$. artemisiifolia afetou negativamente o vigor de sementes de milho e o vigor e a germinação de sementes de soja, sendo a cultura da soja mais sensível aos efeitos alelopáticos do extrato.

O extrato aquoso da parte aérea de A. artemisiifolia apresentou teor de fenóis totais de $11,13 \mathrm{mg} \mathrm{g}^{-1}$ de biomassa seca da parte aérea, o que pode ser considerado um valor alto quando comparado ao de outras infestantes.

\section{REFERÊNCIAS BIBLIOGRÁFICAS}

Almeida, F.S. (1991) - Controle de plantas daninhas no plantio direto. Londrina: IAPAR, 1991. 34 p.

An, M.; Pratley, J. E. \& Haig, T. (2001) - Phytotoxicity of vulpia residues: IV. Dynamics of allelochemicals during decomposition of vulpia residues and their corresponding phytotoxicity. Journal of Chemical Ecology, vol. 27, n. 2, p. 395-409. https://doi.org/10.1023/A:1005692724885

Aquila, M.E.A. (2000) - Efeito alelopático de Ilex paraguariensis A. St.-Hil. na germinação e crescimento inicial de Lactuca sativa L. Iheringia Série Botânica, vol. 53, n. 23, p. 51-66.

Bohren, C. (2007) - Ambrosia artemisiifolia L. - in Switzerland: concerted action to prevent further spreading. Station fédérale de recherches en production végétale, Agroscope Changins Wädenswil (ACW), Nyon, Switzerland. 15 p. [cit. 2017-10-11]. https://www.researchgate.net/publication/242765574_Ambrosia_artemisiifolia_L_-in_Switzerland_concerted_action_to_prevent_further_spreading

Brasil (2009) - Regras para análise de sementes. Ministério da Agricultura, Pecuária e Abastecimento. Brasília: Mapa/ACS. 399 p.

Carvalho, W.P.; Carvalho, G.J.; Abbade Neto, D.O. \& Teixeira, L.G.V. (2014) - Alelopatia de extratos de adubos verdes sobre a germinação e crescimento inicial de alface. Bioscience Journal, vol. 30, p. 1-11.

Chon, S.U.; Coutts, J.H. \& Nelson, C.J. (2000) - Effects of light, growth media, and seedling orientation on bioassays of alfalfa autotoxicity. Agronomy Journal, vol. 92, n. 4, p. 715-720. http:/dx.doi.org/10.2134/ agronj2000.924715x

CONAB (2017) - Acompanhamento da safra brasileira de grãos, safra 2016/2017 - sexto levantamento, Brasilia, $176 \mathrm{p}$.

Corsato, J.M.; Fortes, A.M.T.; Santorum, M. \& Leszczynski, R. (2010) - Efeito alelopático do extrato aquoso de folhas de girassol sobre a germinação de soja e picão-preto. Semina: Ciências Agrárias, vol. 31, n. 2, p. 353-360. http://dx.doi.org/10.5433/1679-0359.2010v31n2p353 
Corrêa, M.P. (1984) - Dicionário de plantas úteis do Brasil. Rio de Janeiro: Ministério da Agricultura, 41p.

DiTommaso, A. (2004) - Germination behavior of common ragweed (Ambrosia artemisiifolia) populations across a range of salinities. Weed Science, vol. 52, p. 1002-1009. https://doi.org/10.1614/WS-04-030R1

Einhellig, F.A. (2004) - Mode of Allelochemical Action of Phenolic Compounds. In: Macías, F.A.; Galindo, J.C.G.; Molinillo, J.M.G. \& Cutler, H.G. (Eds.) - Allelopathy: chemistry and mode of action of allelochemicals. Boca Raton: CRC Press, 2004, p. 217-238.

Ferrarese, M.L.L.; Ferrarese Filho, O. \& Rodrigues, J.D. (2000) - Ferulic acid uptake by soybean root in nutrient culture. Acta Physiologiae Plantarum, vol. 22, n. 2, p. 121-124.

Ferreira, A.G. \& Áquila, M.E.A. (2000) - Alelopatia: uma área emergente da ecofisiologia. Revista Brasileira de Fisiologia Vegetal, vol. 12, p. 175-204.

Ferreira, A.G. (2004) - Interferência: competição e alelopatia. In: Ferreira, A.G. \& Borghetti, F. (Eds.) Germinação do básico ao aplicado. 1ed. Porto Alegre: Artmed, 2004, p. 251-262.

Fenner, M. (2000) - Seeds: the ecology of regeneration in plant communities. Wallingford: CABI Publishing. p. 237-260.

Fujji, Y. \& Hiradate, S. (2007) - Allelopathy: new concepts \& methodology. Enfield: Science Publishers, 382 p.

Gonzalez, H.R.; Mederos, D. \& Sosa, H.I. (2002) - Efectos alelopáticos de restos de diferentes espécies de plantas medicinales sobre la albahaca (Ocimum basilicum L.) em condiciones de laboratório. Revista Cubana de Plantas Medicinales, vol. 7, n. 2, p. 67-72.

Hong, N.H.; Xuan, T.D.; Eiji, T. \& Khanh, T.D. (2004) - Paddy weed control by higher plants from Southeast Asia. Crop Protection, vol. 23, n. 3, p. 255-261. https://doi.org/10.1016/j.cropro.2003.08.008

Iganci, J.R.V.; Bobrowski, V.L.; Heiden, G.; Stein, V.C. \& Rocha, B.H.G. (2006) - Efeito do extrato aquoso de diferentes espécies de boldo sobre a germinação e índice mitótico de Allium cepa L. Arquivos do Instituto Biológico de São Paulo, vol. 73, n. 1, p. 79-82.

Jefferson, L.V. \& Pennachio, M. (2003) - Allelopathic effects of foliage extracts from four Chenopidiaceae species on seed germination. Journal of Arid Environments, vol. 55, n. 2, p. 275-285. https://doi.org/10.1016/S01401963(03)00028-4

Maguire, J.D. (1962) - Speed of germination - aid in selection and evaluation for seedling emergence and vigor. Crop Science, vol. 2, n. 1, p. 176-177.

Marcos-Filho. J.M.; Krzyzanowski, F.C.; Vieira. R.D. \& França Neto, J.B. (1999) - Vigor de sementes: conceitos e testes. Associação Brasileira de Tecnologia em Sementes - ABRATES. Londrina, Paraná, 218p.

Marcos-Filho, J. (2015) - Fisiologia de sementes de plantas cultivadas. Londrina, PR: ABRATES. 659 p.

Muniz, F.R.; Cardoso, M.G.; Von Pinho, E.V.R. \& Villela, M. (2007) - Qualidade Fisiológica de sementes de milho, feijão, soja e alface na presença de extrato de tiririca. Revista Brasileira de Sementes, vol. 29, n. 2, p. 195-204. http://dx.doi.org/10.1590/S0101-31222007000200026

Nakagawa, J. (1999) - Testes de vigor baseados na avaliação das plântulas. In: Vieira, R.D. \& Carvalho, N.M. (Eds.) - Testes de vigor em sementes. Jaboticabal: FUNEP. p. 49-85.

Patterson, D.T. (1981) - Effects of allelopathic chemicals on growth and physiological response of soybean (Glycine max). Weed Science, vol. 29, n. 1, p. 53-58. https://doi.org/10.1017/S0043174500025820

Pinto, T.T.; Fortes, A.M.T. \& Bonamigo, T. (2011) - Efeitos alelopáticos do exsudado radicular de Amaranthus cruentus L. sobre sementes de Glycine max (L.) Merril, Zea mays L. e Bidens pilosa L., Revista de Botânica, vol. 40, p. 13-24. https://doi.org/10.5007/2178-4574.2011n40p13

Politycka, B. (1999) - Ethylene-dependent activity of phenylalanine ammonia-lyase and lignin formation in cucumber roots exposed to phenolic allelochemicals. Acta Societatis Botanicorum Poloniae, vol. 68, n. 2, p. 123-127. https://doi.org/10.5586/asbp.1999.018

Rice, E.L. (1984) - Allelopathy. 2nd. ed. Orlando: Academic Press.

Sampietro, D.A.; Vattuone, M.A. \& Isla, M.I. (2006) - Plant growth inhibitors isoleted from sugarcane (Saccharum officinarum) straw. Journal of Plant Physiology, vol. 163, n. 8, p. 837-846. https://doi.org/10.1016/j. jplph.2005.08.002

Scheren, M.A.; Ribeiro, V.M. \& Nobrega, L.H.P. (2014) - Efeito alelopático de Cyperus rotundus L. no desenvolvimento de plântulas de milho (Zea mays L.). Varia Revista Scientia Agrária, vol. 4, n. 1, p. 105-116. 
Silva, P.B.; Medeiros, A.C.M. \& Duarte, M.C.T. (2011) - Avaliação do potencial alelopático, atividade antimicrobiana e antioxidante dos extratos orgânicos das folhas de Pyrostegia venusta (Ker Gawl.) Miers (Bignoniaceae). Revista Brasileira de Plantas Medicinais, vol. 13, n. 4, p. 447-455. http://dx.doi.org/10.1590/S151605722011000400010

Vasconcelos, M.C.C.; Silva, A.F.A. \& Lima, R.S. (2012) - Interferência de plantas daninhas sobre plantas cultivadas, Agropecuária Científica no Semi-Árido, vol. 8, n. 1. p. 1-6.

Vyvyan, J.R. (2002) - Allelochemicals as leads for newherbicides and agrochemicals. Thetrahedron, vol. 58, n. 9, p. $1631-1646$.

Weiler, C.B.; Frohlich, J.K.; Boligon, A.A.; Janovik, V. \& Athayde, M.L. (2010) - Potencial antioxidante in vitro de folhas de Ipomoea carica L. sweet. Saúde, vol. 36, n. 2, p. 5562.

Yu, J.Q.; Ye, S.F.; Zhang, M.F. \& Hu, W.H. (2003) - Effects of root exudates and aqueous root extracts of cucumber (Cucumis sativus) and allelochemicals, on photosynthesis and antioxidant enzymes in cucumber. Biochemical Systematics and Ecology, vol. 31, n. 2, p. 129-139. https://doi.org/10.1016/S0305-1978(02)00150-3 